Research article

\title{
AN IMMUNOHISTOCHEMICAL STUDY OF COCAINE- AND AMPHETAMINE-REGULATED TRANSCRIPT (CART) EXPRESSION IN THE PTERYGOPALATINE GANGLION OF THE PIG
}

\author{
ZACHARKO-SIEMBIDA Anna*, MATYSEK Małgorzata, SZALAK Radosław, \\ ARCISZEWSKI Marcin B.
}

Department of Animal Anatomy and Histology, Faculty of Veterinary Medicine, University of Life Sciences, Lublin, Poland

(Received 17 January, Accepted 04 May 2017)

\begin{abstract}
Although, a great effort has been made to understand the synthesis, regulation, processing and function of cocaine- and amphetamine-regulated transcript (CART) peptide at the central level, its peripheral function(s) are still obscure. Moreover, scarce studies describing the presence of CART in peripheral autonomic ganglia are mainly limited to laboratory rodents. Thus, the aim of the present study was to immunohistochemically investigate the expression of CART in $\mathrm{Hu} \mathrm{C} / \mathrm{D}$-positive neurons of the porcine pterygopalatine ganglion (PPG). The distribution pattern of CART-IR nerve elements in PPG has been also assessed. The co-localization of CART with substance P (SP), galanin or somatostatin was studied by means of double immunohistochemical stainings. The presence of $\mathrm{Hu} \mathrm{C} / \mathrm{D}$-positive/CART-positive neurons was detected both in the left and right PPG $(4.7 \pm 1.2 \%$ and $5.2 \% \pm 1.4 \%$, respectively). The CARTimmunoreactive (IR) neurons were categorized as either middle (ca. $80 \%$ ) or small (ca. $20 \%)$ in size. Moderate numbers of CART-IR boutons were also detected between CART-negative ganglionic neurons. CART-IR basket-like formations around PPG neurons were regularly observed. Virtually all CART-IR neurons additionally co-stored VIP, whereas none of the CART-expressing cells showed the presence of galanin, SP or somatostatin. CART-IR basket-like formations exclusively encircled VIP-IR PPG neurons. Thus, CART-IR nerve cells seem to constitute a relatively small homologous population of the porcine PPG neurons with largely unknown functions. Further functional studies aiming at whether CART-IR neurons could serve as interneurons are necessary.
\end{abstract}

Key words: autonomic ganglia, immunohistochemistry, neuropeptides, pig, pterygopalatine ganglion

\footnotetext{
*Corresponding author: e-mail: asiembida13@wp.pl
} 


\section{INTRODUCTION}

At the periphery, the parasympathetic division of the autonomic nervous system is represented by small local intramural ganglia, as well as four pairs of large head and neck ganglia, including the pterygopalatine ganglion (PPG). Neuronal tracing studies revealed that in laboratory animals PPG provides parasympathetic innervation to certain organs like the conjunctiva [1], Eustachian tube [2], pineal gland [3], choroid [4] or lacrimal gland [5]. With the use of Bartha strain pseudorabies virus (retrograde transneuronal tracer) it has been determined that PPG receives preganglionic input predominantly from the superior salivatory nucleus of the facial motor complex but also from discrete brain regions like paraventricular nucleus of the hypothalamus, the periaqueductal gray, the raphe magnus, the pons, the nucleus of the solitary tract (NTS), the rostral ventrolateral medulla and the intermediate reticular nucleus of the medulla [6]. From the morphological point of view, at least two different forms of PPG can be distinguished. Precise macroanatomical studies revealed that PPG may exist as either a large aggregation of nerve cells grouped in a single ganglion or a small plexus containing several smaller in size ganglia [7]. Previous studies have also shown that PPG parasympathetic neurons are predominantly cholinergic by nature, however the presence of other neurotransmitter markers including tyrosine hydroxylase or nitric oxide synthase has been additionally noted [7]. Besides, major neurotransmitter PPG neurons also express various neuropeptide receptors [8] as well as a bulk of neuroactive peptides acting as neuromodulators and/or co-transmitters [9-11]. Recently, the presence of novel multipotent neuropeptide cocaine- and amphetamineregulated transcript (CART) has been found in a small subset of the rat's [12] and the duck's [13] PPG neurons, however the full meaning of this finding is still obscure. Numerous observations clearly showed that CART widely expressed throughout the central nervous system has been implicated in a variety of functions including feeding and food intake, stress, reward and reinforcement and many more (for recent review see [14]). However, the role(s) of CART at the periphery (in particular in the autonomic parasympathetic ganglia) may vary from those observed at the central level. Besides the physiological aspects, previous studies additionally raised the question whether and to what extend CART is expressed in PPG of higher mammals. Therefore, the aim of the present study was to immunohistochemically determine the distribution pattern of CART in PPG of the pig. Double immunohistochemical stainings were also applied in order to figure out whether in PPG neurons CART may functionally co-operate with galanin, vasoactive intestinal polypeptide (VIP), somatostatin or substance P (SP).

\section{MATERIAL AND METHODS}

Animals and tissue samples. The experimental procedures were carried out in accordance with specific Polish and international laws and regulations and in accordance with the principles approved by the Local Ethical Committee at the University of Life 
Sciences in Lublin, Poland. Bilateral pterygopalatine ganglia from five $(n=5) 6$ weeks old piglets (weighing approx. $25 \mathrm{~kg}$ each) were dissected out. Piglets were initially sedated with azaperone (Stresnill, Pharmacia Upjon, Poland $0.5 \mathrm{mg} / \mathrm{kg}$ b.w.) and killed by an overdose of sodium pentobarbital (Morbital, Biowet Puławy, Poland $50 \mathrm{mg} / \mathrm{kg}$ b.w.). After dissection, the ganglia were immediately washed in $0.9 \% \mathrm{NaCl}$ followed by fixation in 15\% saturated picric acid and 2\% paraformaldehyde fixative solution for 24 $\mathrm{h}$ at room temperature (RT). After the fixation, tissue samples were rinsed well in PBS (3 x $10 \mathrm{~min}$ ) and subsequently stored in $30 \%$ sucrose at $4^{\circ} \mathrm{C}$ for at least 4 days (every day the sucrose solution was renewed). Next, the tissues were carefully embedded in OCT compound (Sakura, Finetek, Tokyo, Japan) and quickly frozen on dry ice. The material was sectioned on a cryostat at a thickness of $10 \mu \mathrm{m}$. Every fifth section was mounted onto a glass slide (SuperFrost ${ }^{\circledR}$ Plus, Menzel-Gläser, Thermo Scientific, Braunschweig, Germany) and stored at $-20^{\circ} \mathrm{C}$ until use.

Immunohistochemistry. In general, for immunohistochemical studies the staining protocol described elsewhere was used [15]. In brief, cryostat sections were first allowed to air dry 15 min at RT. Rehydration of the sections was completed with a rinse $(3 \times 15$ min) in $0.01 \mathrm{M}$ phosphate buffered saline (PBS, $\mathrm{pH}$ 7.4) supplemented with enhancing antibodies penetration $0.25 \%$ Triton X-100, $10 \%$ normal goat serum and $0.25 \%$ bovine serum albumin (Sigma Aldrich, Germany). Next, the slides were placed in humidified staining chamber and incubated overnight (RT) with a mixture of primary antibodies. For the detection of CART in ganglionic neurons rabbit anti-CART ${ }_{(62-102)}$ primary antisera (1:10000; Phoenix Pharmaceuticals, USA; code H-003-61) were combined with mouse anti-HuC/D (panneuronal marker) primary antibodies (1:800; Molecular Probes, USA; code A-21271). For the co-localization studies, anti-CART antibodies were mixed with one of the following sera: mouse anti-VIP $(1: 100$; Biogenesis, UK; code 9535-0504), rat anti-SP (1:400; AbD Serotec, UK; code 8450-0505), rat antisomatostatin (1:300; AbD Serotec, UK; code 8330-0009). The bound antigen-primary antibody complexes were visualized using Texas Red-conjugated anti-rabbit goat IgG (1:400; MP Biomedicals, Solon, OH, USA) and either FITC-conjugated anti-mouse goat IgG (1:400; MP Biomedicals, Solon, OH, USA) or FITC-conjugated anti-rat goat IgG (1:400; MP Biomedicals, Solon, OH, USA) secondary antibodies. After a final wash in PBS (3x15 min) each slide was coverslipped using PBS-glycerol as a mounting medium. The sections were examined and photographed using a spinning disk confocal microscope (BX-DSU Olympus, Nagano, Japan) equipped with interference filters optimized for the detection of red and green fluorochromes (MINIBA2 and MWIY2, respectively). Control specimens were processed in the same manner, but the primary antibody was either omitted or replaced with normal goat serum. Additionally, the specificities of primary antibodies were verified in blocking tests, when the primary antibody was pre-adsorbed with an excess amount of the corresponding synthetic antigen.

Counting procedure and statistics. The numbers of double-labeled PPG neurons were counted. All numerical data were presented as mean \pm SEM. Relative numbers of 
CART-immunoreactive (IR) right and left PPG neurons were quantified. In each of the PPG studied all Hu C/D-IR neurons with a well-visible nucleus were studied for the simultaneous presence of CART. In each animal, neuronal counts were performed on a random sample of a minimum of 100 ganglionic neurons. In each animal, no less than 30 microscopic fields were analyzed at a magnification of 100x. The proportions of CART-IR neurons were presented as a percentage of the total number of perikarya. The long axis of CART-positive neurons (no less than 100 perikarya with well visible nucleus) was measured. Based on the diameter, CART-IR neurons were arbitrarily classified as small (up to $35 \mu \mathrm{m}$ ), middle (between 35 and $50 \mu \mathrm{m}$ ) and large (above $50 \mu \mathrm{m}$ ) in size. For co-localization studies, all the cell bodies that were found to be immunopositive to CART (but no less than 50) were examined for the presence of the second substance. The proportions of CART-IR neurons co-expressing neuropeptides were presented as percentages of the total number of CART labeled neurons. The densities of nerve fibers IR to CART and/or other peptides were visually assessed using the following semi-quantitative scale: absent (-), single $(+)$, moderate $(++)$, numerous $(+++)$ and very numerous $(++++)$. In order to determine differences between homologous neuronal phenotypes of the right and left PPG a two-way analysis of variance (ANOVA) test was applied. A probability of $\mathrm{P}<0.05$ was the level of significance in all studies.

\section{RESULTS}

Immunoreactivity to CART. In general, in all experimental animals PPG appeared to be in fact the ganglionated plexus comprised by one main larger ganglion and a few smaller ones. The expression of CART was found both in the main ganglion and adjacent small ganglia. Immunoreactivity to CART was seen both in $\mathrm{Hu}$ C/D-positive neuronal cell bodies as well as moderately numerous nerve terminals distributed between the PPG neurons (Fig. 1A, A'). In nerve branches interconnecting the neighboring ganglia single, fine and mainly varicose CART-IR nerve terminals were observed (Fig. 1B). The observed $\mathrm{Hu} \mathrm{C} / \mathrm{D}-\mathrm{IR} / \mathrm{CART}$-IR neurons were randomly and evenly distributed throughout PPG with no peculiar pattern. In the left PPG, the expression of CART was noted in $4.7 \pm 1.2 \%$ of $\mathrm{Hu} \mathrm{C} / \mathrm{D}$-IR ganglionic neurons whereas in the right PPG the proportions of $\mathrm{Hu} \mathrm{C} / \mathrm{D}-\mathrm{IR} / \mathrm{CART}$-IR neurons were calculated to $5.2 \% \pm 1.4 \%$. No statistical differences between percentages of CART-expressing neurons were found between the left and right PPG ( $<<0.05)$. The vast majority (approx. 80\%) of CART-IR neurons were categorized as middle in size whereas remaining $20 \%$ were small in size. In general, CART-IR nerve terminals were regularly observed as a bright spot-like, however in some cases CART-IR basket-like formations encircling particular CART-negative perikarya were observed.

Co-localization studies. In both the right and left PPG, none of the CART-IR neurons additionally co-expressed galanin (Fig. 2A). Likewise, none of galanin-expressing nerve fibers found within PPG as well as in interganglionic nerve branches showed the 
presence of CART. Moreover, a very clear difference in appearance between CARTpositive and galanin-positive nerve terminals were seen; the latter were frequently observed as long non-varicose nerve strands. Additionally, the numbers of CARTIR nerve terminals visually outnumbered that of galanin-IR. In some cases, CARTIR nerve terminals run in a close vicinity to galanin-IR PPG neurons but none of the observed CART-IR basket-like formations encircled galanin-positive neurons. In virtually all CART-IR neurons the presence of VIP was found (Fig. 2B). However, in CART-IR nerve terminals present in PPG no co-localization with VIP was observed. Additionally, CART-IR basket-like formations were found to encircle solely CARTnegative/VIP-positive neurons (Fig. 2B). VIP-positive nerve processes deriving directly from VIP-positive PPG neurons were not in contact with either CART-IR neurons or CART-IR ganglionic nerve terminals. Immunoreactivity to SP was not observed in ganglionic neurons. Very numerous SP-IR/CART-negative nerve fibers were found in nerve strands interconnecting neighboring ganglia. In particular ganglia, sparse SP-IR nerve fibers lacking CART were also found. SP-IR nerve fibers were found to run in a far distance from CART-IR/SP-negative neurons. The varicose CART-IR nerve terminals located between ganglionic neurons showed no SP-expression (Fig. 2C). Both in PPG as well as in nerve strands interconnecting particular ganglia no colocalization between CART and somatostatin was found (Fig. 2D).

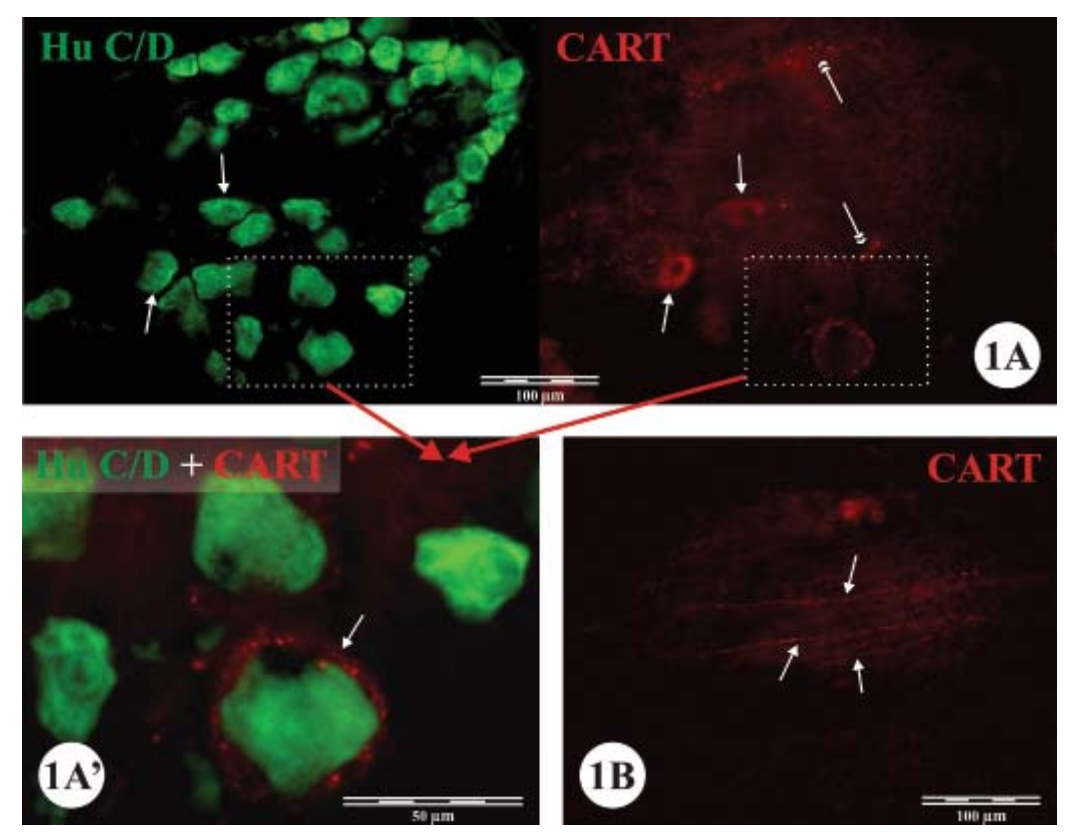

Figure 1. Expression of CART in PPG of the pig (1A). Amongst numerous Hu C/Dimmunoreactive (IR) PPG neurons only two (arrows) are immunopositive to CART. (1 $\mathrm{A}^{\prime}$ ) is a combined higher magnification image of selected areas in (1A) and presents a CART-IR basketlike formation (arrow) around PPG HuC/D-IR neuron. (1B) illustrates the presence of CART in nerve fibres running in nerve strands interconnecting neighboring pterygopalatine ganglia. 

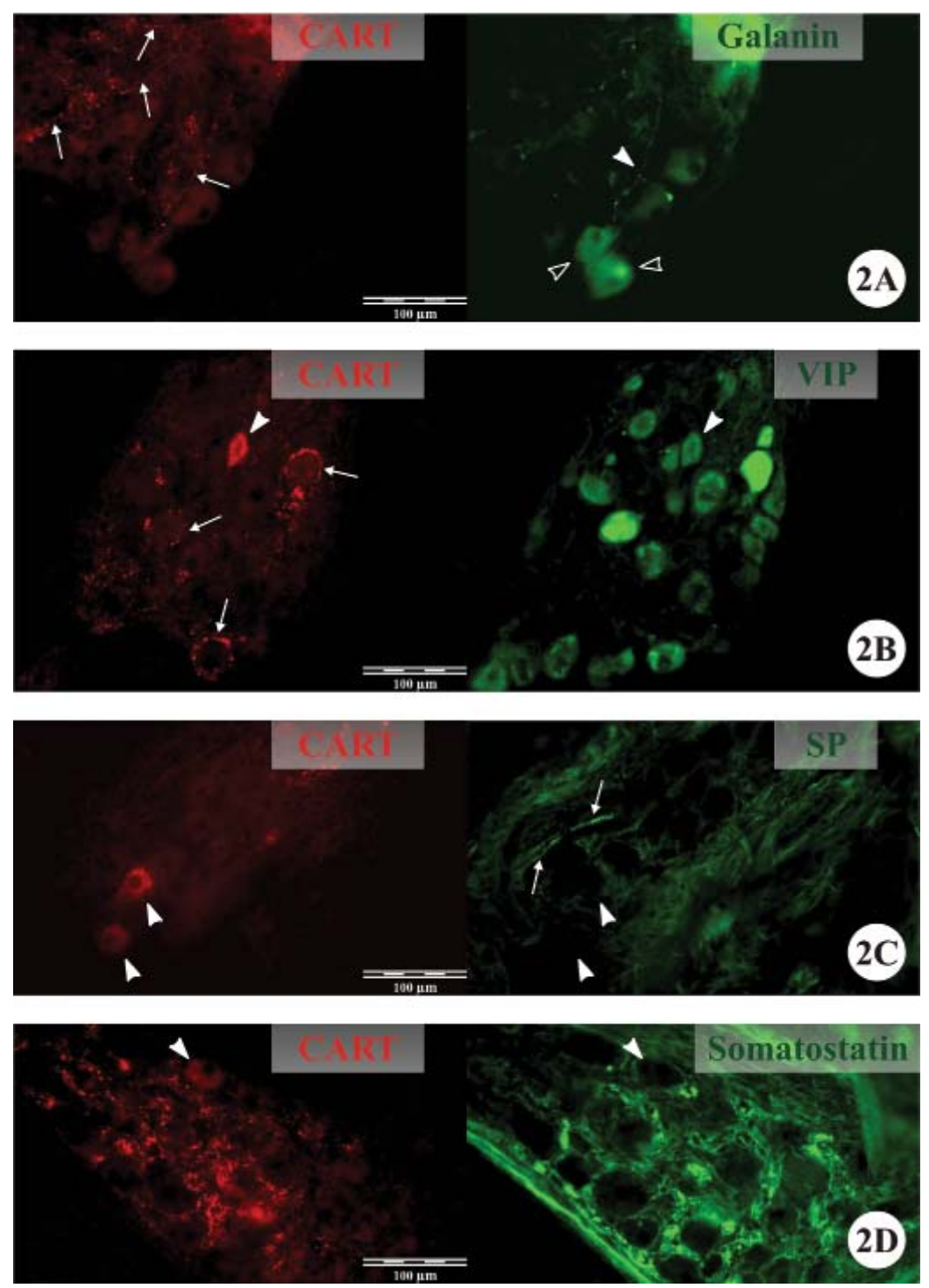

Figure 2. Paired fluorescent micrographs illustrating results of double immunohistochemical stainings. Figure (2A) shows that galanin-immunoreactive (IR) PPG neurons (arrowheads) are negative for CART. Additionally, in (2A) the presence of CART-positive/galanin-negative nerve terminals (arrows) as well as galanin-positive/CART-negative ganglionic nerve fibres (arrowhead) are seen. In (2B), CART-IR/VIP-IR PPG neuron is marked with arrowhead whereas arrows point to CART-IR basket-like formations around CART-negative/VIPpositive neurons. Figure (2C) presents CART-IR neurons lacking SP (arrowheads) as well as SP-positive/CART-negative ganglionic nerve fibres (arrows). (2D) depicts no co-localization between CART and somatostatin in the porcine PPG (arrowhead marks CART-IR/ somatostatin-negative neuron). 


\section{DISCUSSION}

In the present study, the expression pattern of CART was evaluated for the first time in the porcine PPG. The obtained results indicated the existence of a minor population (approx. 5\%) of middle-sized CART-ergic neurons in the porcine PPG. Another original observation is that in the porcine PPG a moderately dense CART-IR nerve terminals plexus is present. These findings are, in general, in line with the results of previous studies as Ivanusic et al. [12] have immunohistochemically determined that as many as $5.25 \%$ of the rat sphenopalatine ganglionic neurons express CART. Although no direct correlation to mammals could be easily given it is worth to mention that in the duck, the expression of CART in neurons of both superior and inferior PPG was relatively very high and amounted to 83-85\% [13]. The outlined differences between the proportions of CART-ergic neurons in the mammalian and avian PPG suggest the presence of species-related differences. Interestingly in the rat, a relatively small population of CART-IR neurons (approx. 4\%) was observed in the other head parasympathetic otic ganglion [12] whereas in more peripherally located parasympathetic intracardiac ganglia immunoreactivity to CART was present in approx. $46 \%$ of periakrya [16]. Noteworthy, in the latter study no presence of CARTIR nerve terminals forming pericellular baskets around intracardiac neurons were found. Similarly to our findings, the presence of low density CART-IR nerve plexus between PPG ganglionic neurons was recognized in the duck [13], whereas no such kind of data has been presented in relation to the rat's PPG. Taking into account the above, it is possible, that in particular porcine PPG ganglia CART-IR nerve terminals may originate from CART-positive central neurons and/or other PPG CART-IR ganglionic neurons. However, so far the expression of CART in the porcine brain was predominantly found in the amygdala [17], hippocampus [18] or preoptic area [19] but not in the previously mentioned central nuclei which are known to project to PPG [6]. Our hypothesis that the observed CART-IR nerve terminals found in particular pterygopalatine ganglia may originate (at least partially) from the neighboring ganglia may be additionally supported by the finding that single CART-IR nerve fibers were observed in nerve branches interconnecting particular ganglia. Thus, it is also possible that CART-IR PPG neurons may serve as interneurons. Previously, CART-expressing interneurons were identified in the rat's spinal intermediolateral cell column [20] and dorsal horn [21] or in the enteric plexuses of the guinea-pig's bowel [22]. Not much is known about other possible targets of CART-expressing PPG neurons. In a previous experimental study utilizing Fast Blue $(\mathrm{FB})$ retrograde tracer it has been shown that after FB injection into the rat lacrimal gland approx. 30\% of FB-labeled neurons showed immunoreaction to CART [12]. The same authors additionally identified in the rat PPG FB-positive neuronal populations supplying the nasal mucosa or tempomandibular joint, however amongst those FB-positive neurons only single showed the presence of CART [12]. These data indicated the possible role of CART as secretory factor involved in lacrimation and/or as regulator of the blood flow through the lacrimal gland. Vasoactive properties of CART have been previously demonstrated 
in the cerebral circulation because extra- or intraluminal CART application resulted in long-lasting cerebral arterioles constriction [23]. Noteworthy it is also well known, that CART in certain conditions (like type 2-diabetes) acts as regulator of islet hormone secretion [24].

In the present study, we have found that virtually all CART-IR PPG neurons additionally co-expressed VIP. VIP is widely expressed in parasympathetic neurons. In the rat and human, VIP could even serve as a marker of PPG neurons because in those species 99\% of PPG neurons express this neuropeptide [9]. In the porcine PPG all VIP-ergic PPG neurons are cholinergic in nature [11]. The co-localization of CART and VIP is additionally regularly found in the mammalian intrapancreatic neurons [25], enteric neurons from the stomach [26], small intestine [27] and large intestine [28]. Taking into account the above it is possible that in PPG neurons, CART and VIP could interplay in the regulation of the lacrimal gland activities. Our hypothesis may be supported by the findings that numerous VIP-IR nerve terminals are present in the rat lacrimal gland and VIP was found to stimulate protein secretion from the lacrimal gland acini [29].

The present finding indicates clearly that the porcine CART-IR PPG neurons do not express galanin. So far, no studies describing the co-localization pattern of CART and galanin in mammalian PPG are available. It has been immunohistochemically demonstrated that in the porcine PPG galanin-containing neurons constitute up to $6 \%$ of all neuronal perykarya [11]. It has been postulated that galanin-containing PPG neurons are considered as a source of nerve supply to blood vessels (ciliary artery and choroidal blood vessels) of the cat's eye [30]. On the other hand the presence of galanin-IR nerve fibres was also discovered in the porcine lacrimal gland [31]. Inhibitory action of galanin on parasympathetic cholinergic transmission [32] may be due to the facts that in parasympathetic neurons galanin activates inward potassium current and inhibits barium current [33]. Since a similar vasoregulatory role of CART has been previously demonstrated, one could expect that galanin and CART should be co-stored in the same PPG neurons. Because these two neuropeptides are not costored in PPG neurons and no CART-IR basket-like formations encircling galanincontaining PPG neurons have been found we suggest that galanin and CART do not functionally co-operate. In the present study we did not observe SP-IR PPG neurons which is line with previous findings [11]. We also discovered that populations of SP-IR ganglionic nerve fibres and CART-IR nerve terminals showed different distribution patterns. Using anterograde tracing technique it has been demonstrated that SP-IR nerve fibers present in the rat PPG are in fact sensory nerve fibers arising from the trigeminal ganglion [34]. Because in the present study, SP-IR nerve fibers were not in close contact to CART-IR PPG neurons we speculate that the sensory system has no influence on the CART-related neurotransmission of parasympathetic PPG neurons. Interestingly, we failed to visualize somatostatin-IR neuronal elements in the porcine PPG. Previously, it has been reported that a relatively small subpopulation of somatostatin-IR small-sized neurons exists in the porcine [11] and chinchilla's PPG [7]. 
The possible explanations of the observed discrepancies in somatostatin expression in the mammalian PPG may be the immunoproperties on the antibodies used or the existence of species-related differences. However, it is of importance to mention that anti-somatostatin antisera used in the present study were tested and successfully applied in other experiments [35-37].

In summary, we reported a comprehensive description of CART expression in the porcine PPG. In co-localization studies we specified the chemical coding of CART-IR PPG neurons. We found that CART-IR neurons co-express VIP but not SP, galanin and somatostatin. Because CART-IR nerve terminals regularly encircled VIP-IR neurons a role of CART in interneuronal transmission has been postulated.

\section{Authors' contributions}

ZSA made conception and designed the study, dissected out the material, carried out immunohistochemical stainings, drafted the manuscript. MM processed microscope fluorescent images. SR performed the statistical analysis. AMB revised the manuscript critically for important intellectual content.

\section{Declaration of conflicting interests}

The author(s) declared no potential conflicts of interest with respect to the research, authorship, and/or publication of this article.

\section{REFERENCES}

1. ten Tusscher MP, Klooster J, Vrensen GF: The innervation of the rabbit's anterior eye segment: a retrograde tracing study. Exp Eye Res 1998, 46:717-730.

2. Oyagi S, Ito J, Honjo I: The origin of autonomic nerves of the Eustachian tube as studied by the horseradish peroxidase tracer method. Acta Otolaryngol 1988, 105:266-272.

3. Shiotani Y, Yamano M, Shiosaka S, Emson PC, Hillyard CJ, Girgis S, MacIntyre I: Distribution and origins of substance P (SP)-, calcitonin gene-related peptide (CGRP)-, vasoactive intestinal polypeptide (VIP)- and neuropeptide Y (NPY)-containing nerve fibers in the pineal gland of gerbils. Neurosci Lett 1986, 70:187-192.

4. Cuthbertson S, LeDoux MS, Jones S, Jones J, Zhou Q, Gong S, Ryan P, Reiner A: Localization of preganglionic neurons that innervate choroidal neurons of pterygopalatine ganglion. Invest Ophthalmol Vis Sci 2003, 44:3713-3724.

5. Beckers HJ, Klooster J, Vrensen GF, Lamers WP: Facial parasympathetic innervation of the rat choroid, lacrimal glands and ciliary ganglion. An ultrastructural pterygopalatine tracing and immunohistochemical study. Ophthalmic Res 1993, 25:319-330.

6. Li C, Fitzgerald ME, Del Mar N, Cuthbertson-Coates S, LeDoux MS, Gong S, Ryan JP, Reiner A: The identification and neurochemical characterization of central neurons that target parasympathetic preganglionic neurons involved in the regulation of choroidal blood 
flow in the rat eye using pseudorabies virus, immunolabeling and conventional pathway tracing methods. Front Neuroanat 2015, 9:65.

7. Szczurkowski A, Sienkiewicz W, Kuchinka J, Kaleczyc J: Morphology and immunohistochemical characteristics of the pterygopalatine ganglion in the chinchilla (Chinchilla laniger, Molina). Pol J Vet Sci 2013, 16:359-368.

8. Shimizu T, Morris JL, Gibbins IL: Expression of immunoreactivity to neurokinin-1 receptor by subsets of cranial parasympathetic neurons: correlation with neuropeptides, nitric oxide synthase, and pathways. Exp Neurol 2001, 172:293-306.

9. Motosugi H: Immunohistochemical observation of neurotransmitters in rat and human pterygopalatine ganglia. Nihon Jibiinkoka Gakkai Kaiho 1993, 96:936-945.

10. Liu J, Evans MS, Brewer GJ, Lee TJ: N-type $\mathrm{Ca}^{2+}$ channels in cultured rat sphenopalatine ganglion neurons: an immunohistochemical and electrophysiological study. J Cereb Blood Flow Metab 2000, 1:183-191.

11. Podlasz P, Wąsowicz K, Kaleczyc J, Lakomy M, Bukowski R: Localization of immunoreactivities for neuropeptides and neurotransmitter-synthesizing enzymes in the pterygopalatine ganglion of the pig. Vet Med - Czech 2003, 48:99-107.

12. Ivanusic JJ, Goulding KE, Kwok MM, Jennings EA: Neurochemical classification and projection targets of CART peptide immunoreactive neurons in sensory and parasympathetic ganglia of the head. Neuropeptides 2012, 46:55-60.

13. Radzimirska M, Bogus-Nowakowska K, Kuder T, Robak A: Distribution of cocaine- and amphetamine-regulated transcript (CART), neuropeptide Y (NPY) and galanin (GAL) in the pterygopalatine ganglion of the domestic duck (Anas platyrbynchos $f$. domestica). Folia Histochem Cytobiol 2016, 54:25-31.

14. Rogge G, Jones D, Hubert GW, Lin Y, Kuhar MJ: CART peptides: regulators of body weight, reward and other functions. Nat Rev Neurosci 2008, 9:747-758.

15. Arciszewski MB, Zacharko-Siembida A: A co-localization study on the ovine pancreas innervation. Ann Anat 2007,189:157-67.

16. Richardson RJ, Grkovic I, Anderson CR: Cocaine- and amphetamine-related transcript peptide and somatostatin in rat intracardiac ganglia. Cell Tissue Res 2006, 324:17-24.

17. Równiak M, Robak A, Bogus-Nowakowska K, Wasilewska B, Najdzion J, Majewski M: The cocaine- and amphetamine-regulated transcript (CART) immunoreactivity in the amygdala of the pig. Anat Histol Embryol 2010, 39:385-397.

18. Kolenkiewicz M, Robak A, Równiak M, Bogus-Nowakowska K, Całka J, Majewski M: Distribution of cocaine- and amphetamine-regulated transcript in the hippocampal formation of the guinea pig and domestic pig. Folia Morphol (Warsz) 2009, 68:23-31.

19. Bogus-Nowakowska K, Robak A, Równiak M, Wasilewska B, Najdzion J, Kolenkiewicz M, Zakowski W, Majewski M: Distribution and chemical coding pattern of the cocaine- and amphetamine-regulated transcript (CART) immunoreactivity in the preoptic area of the pig. Folia Histochem Cytobiol 2011, 49:604-614.

20. Fenwick NM, Martin CL, Llewellyn-Smith IJ: Immunoreactivity for cocaine- and amphetamine-regulated transcript in rat sympathetic preganglionic neurons projecting to sympathetic ganglia and the adrenal medulla. J Comp Neurol 2006, 495:422-433.

21. Kozsurek M, Lukácsi E, Fekete C, Wittmann G, Réthelyi M, Puskár Z: Cocaine- and amphetamine-regulated transcript peptide (CART) is present in peptidergic C primary afferents and axons of excitatory interneurons with a possible role in nociception in the superficial laminae of the rat spinal cord. Eur J Neurosci 2007, 26:1624-1631. 
22. Ellis LM, Mawe GM: Distribution and chemical coding of cocaine- and amphetamineregulated transcript peptide (CART)-immunoreactive neurons in the guinea pig bowel. Cell Tissue Res 2003, 312:265-274.

23. Iliff JJ, Alkayed NJ, Gloshani KJ, Traystman RJ, West GA: Cocaine- and amphetamineregulated transcript (CART) peptide: a vasoactive role in the cerebral circulation. J Cereb Blood Flow Metab 2005, 25:1376-1385.

24. Banke E, Riva M, Shcherbina L, Wierup N, Degerman E: Cocaine- and amphetamineregulated transcript is expressed in adipocytes and regulate lipid- and glucose homeostasis. Regul Pept 2013, 182:35-40.

25. Wierup N, Gunnarsdóttir A, Ekblad E, Sundler F: Characterisation of CART-containing neurons and cells in the porcine pancreas, gastro-intestinal tract, adrenal and thyroid glands. BMC Neurosci 2007, 8:51.

26. Arciszewski MB, Barabasz S, Skobowiat C, Maksymowicz W, Majewski M: Immunodetection of cocaine- and amphetamine-regulated transcript in the rumen, reticulum, omasum and abomasum of the sheep. Anat Histol Embryol 2009, 38:62-67.

27. Wojtkiewicz J, Gonkowski S, Bladowski M, Majewski M: Characterisation of cocaine- and amphetamine- regulated transcript-like immunoreactive (CART-LI) enteric neurons in the porcine small intestine. Acta Vet Hung 2012, 60:371-381.

28. Bulc M, Gonkowski S, Landowski P, Kamińska B, Całka J: Immunohistochemical evidence of the co-localisation of cocaine and amphetamine regulatory peptide with neuronal isoform of nitric oxide synthase, vasoactive intestinal peptide and galanin within the circular muscle layer of the human caecum. Folia Morphol (Warsz) 2015, 74:176-182.

29. Dartt DA, Baker AK, Vaillant C, Rose PE: Vasoactive intestinal polypeptide stimulation of protein secretion from rat lacrimal gland acini. Am J Physiol 1984, 247:G502-G509.

30. Grimes PA, McGlinn AM, Koeberlein B, Stone RA: Galanin immunoreactivity in autonomic innervation of the cat eye. J Comp Neurol 1994, 348:234-243.

31. Adeghate E, Singh J: Immunohistochemical identification of galanin and leucin-enkephalin in the porcine lacrimal gland. Neuropeptides 1994, 27:285-289.

32. Nishimura T, Akasu T: Galanin causes presynaptic inhibition of cholinergic transmission in rabbit parasympathetic ganglia. Kurume Med J 1995, 42:45-48.

33. Parsons RL, Mulvaney JM, Merriam LA: Galanin activates an inwardly rectifying potassium conductance and inhibits a voltage-dependent calcium conductance in mudpuppy parasympathetic neurons. Ann N Y Acad Sci 1998, 863:156-169.

34. Beckers HJ, Klooster J, Vrensen GF, Lamers WP: Ultrastructural identification of trigeminal nerve terminals in the pterygopalatine ganglion of rats: an anterograde tracing and immunohistochemical study. Brain Res 1991, 557:22-30.

35. Pidsudko Z, Kaleczyc J, Wasowicz K, Sienkiewicz W, Majewski M, Zajac W, Lakomy M: Distribution and chemical coding of intramural neurons in the porcine ileum during proliferative enteropathy. J Comp Pathol 2008, 138:23-31.

36. Pidsudko Z: Immunohistochemical characteristics and distribution of sensory dorsal root Ganglia neurons supplying the urinary bladder in the male pig. J Mol Neurosci 2014, 52:7181.

37. Zacharko-Siembida A, Arciszewski MB: Cocaine- and amphetamine-regulated transcriptlike immunoreactivity (CART-LI) in intramural ganglia of porcine urinary bladder trigone. Med Weter 2014, 70:594-598. 


\title{
IMUNOHISTOHEMIJSKA ISPITIVANJA EKSPRESIJE KOKAIN \\ I AMFETAMIN REGULISANIH TRANSKRIPTA (CART) U PTERIGOPALATINSKOM GANGLIONU SVINJA
}

\author{
ZACHARKO-SIEMBIDA Anna, MATYSEK Małgorzata, SZALAK Radosław, \\ ARCISZEWSKI Marcin B.
}

Uprkos velikim naporima da se razume sinteza, regulacija, metabolizam i funckija kokain i amfetamin regulisanih transkripta (CART) peptida na centralnom nivou, ipak su periferne funkcije još uvek nejasne. Štaviše, mali broj studija koje opisuju prisustva CART u perifernim autonomnim ganglijama ograničen je na laboratorijske vrste životnja tj. glodare. Iz tog razloga, cilj studije je bio da se imunohistohemijski ispita ekspresija CART kod Hu C/D pozitivnim neuronima pterigopalatinskom ganglionu svinja (PPG). Istovremeno, obavljena je i procena distribucije CART-IR nervnih elemenata u PPG. Ko-lokalizacija CART sa P substancijom (SP), galaninom ili somatostatinom je ispitivana pomoću dvostrukih imunohistohemijskih bojenja. Prisustvo Hy C/D-pozitivnih/CART-pozitivnih neurona je uočena kako u levom tako i u desnom PPG $(4,7 \pm 1,2 \%$ odosno 5,2\% $\pm 1,4 \%)$. Kategorizacija po veličini CARTimunoreaktivnih (IR) neurona je bila srednja (oko 80\%) ili mala (oko 20\%). Srednji broj CART-IR tačaka je takođe uočen između CART-negativnih ganglijskih neurona. Standardni nalaz su bile formacije CART-IR nalik na vreće koje su se nalazile oko PPG neurona. Praktično su svi CART-IR neuroni dodatno VIP akumulirani. Ni jedna ćelija koja je eksprimirala CART, nije pokazala prisustvo galanina, SP ili somatostatina. CART-IR formacije koje su nalikovale na vreće, isključivo su se nalazile oko VIUPIR PPG neurona. Rezultati ukazuju da CART-IR nervne ćelije predstavljaju lelativno malu homogenu populaciju PPG svinjskih neurona čija funkcija još uvek nije poznata. Neophodno je da se obave dalje studije sa ciljem da se razjasni da li CART-IR neuroni igraju ulogu interneurona. 